\title{
Bohemian graduates in the UK: disciplines and location determinants for entering creative careers
}

Article

Accepted Version

Faggian, A., Communian, R., Jewell, S. and Kelly, U. (2013) Bohemian graduates in the UK: disciplines and location determinants for entering creative careers. Regional Studies, 47 (2). pp. 183-200. ISSN 1360-0591 doi:

https://doi.org/10.1080/00343404.2012.665990 Available at https://centaur.reading.ac.uk/29707/

It is advisable to refer to the publisher's version if you intend to cite from the work. See Guidance on citing.

To link to this article DOI: http://dx.doi.org/10.1080/00343404.2012.665990

Publisher: Routledge

All outputs in CentAUR are protected by Intellectual Property Rights law, including copyright law. Copyright and IPR is retained by the creators or other copyright holders. Terms and conditions for use of this material are defined in the End User Agreement.

www.reading.ac.uk/centaur 
Central Archive at the University of Reading

Reading's research outputs online 


\title{
Bohemian graduates in the UK: disciplines and location determinants of creative careers
}

\author{
THIS IS A DRAFT VERSION - the final version of this paper will be published in a \\ forthcoming issue of Regional Studies. \\ Faggian, A., Comunian, R., Jewell S. and U. Kelly (forthcoming) Bohemian graduates in the \\ UK: disciplines and location determinants of creative careers, Regions Studies \\ For updated information on how to best reference the paper contact R.Comunian@kent.ac.uk
}

\begin{abstract}
Alessandra Faggian, Associate Professor, AED Economics Department, The Ohio State University, 2120 Fyffe Road, Columbus, Ohio 43210 (USA), E-mail: faggian.1@osu.edu,

Roberta Comunian, School of Arts, University of Kent, Jarman Building, Canterbury, Kent, CT2 7UG, (UK), Email: R.Comunian@kent.ac.uk

Sarah Jewell, School of Economics, Whiteknights, PO Box 217, READING, Berkshire, RG6 6AH, (UK), E-mail: s.l.jewell@reading.ac.uk

Kelly, Ursula, University of Strathclyde, Department of Economics, Sir William Duncan Building, 130 Rottenrow, G4 OGE (UK), E-mail: u.kelly@strath.ac.uk
\end{abstract}

\begin{abstract}
:
The human capital and regional economic development literature has become increasingly interested in the role of the 'Bohemian occupations' on economic growth. Using UK higher education student micro-data, we investigate the characteristics and location determinants of creative (bohemian) graduates. We examine three specific sub-groups: creative arts \& design graduates; creative media graduates; other creative graduates. We find these disciplines influence the ability of graduates to enter creative occupations and be successful in the labour market. We also highlight the role of geography, with London and the South East emerging as hubs for studying and providing Bohemian graduates with more labour market opportunities.

Keywords: creative class, human capital, higher education, labour market, regional economics

JEL codes:

- J4 - Particular Labor Markets < J - Labor and Demographic Economics,

- J24 - Human Capital|Skills|Occupational Choice|Labor Productivity

- 12 - Education < I - Health, Education, and Welfare,

- R1 - General Regional Economics < R - Urban, Rural, and Regional Economics
\end{abstract}

1. Introduction

The past ten years have witnessed a surge of attention, by both the academic community and policy makers, on the importance of 'creativity' in fostering economic development. This surge has been mainly connected to the work by Florida (2002) who pointed out how talented and skilled people - labeled 'creative class' - are now the real key to today's world success and, for this reason, are in constant demand around the world.

Ever since the publication of Florida's 'The Rise of the Creative Class' (2002) followed by 'The Flight of the Creative Class' (2006) the debate has heated up. Despite not denying the vital role of 'creative' people for economic success, most economists have highly criticized 
Florida. One of the main criticisms has been that concepts such as 'creative class' and 'talent' seemed to be defined in a somewhat vague way, without explicitly recognising their links to the well-established concept of human capital (GLAESER, 2005) and its links to local development (FAGGIAN and MCCANN, 2006, 2009a, b). Although this point is not discussed in the current paper as it has been already addressed elsewhere (COMUNIAN et al., 2010), it is important to note that Florida himself - and co-authors - in some of their more recent contributions (FLORIDA et al., 2008; MELLANDER, 2009; MELLANDER and FLORIDA, 2007) did recognize the need to better elucidate the relationship between creative class and human capital. The second criticism moved to the 'creative class' concept is that it seems to include a very heterogeneous group of individuals, who can hardly be considered a 'class'. Markusen (2006), sees the definition of creative class as an artificial construction which merges together different occupations (e.g. artistic occupations with engineering, science and technology ones) with very little in common. Markusen and Schrock (2006) highlight the need to use a narrower definition of creative class (i.e. limited to artistic occupations) to understand the core dynamics of the creative sector and better estimate its contribution to local and regional development. Comunian et al. (2010) showed that, in fact, the career dynamics of people who study artistic subjects (called Bohemian graduates) are completely different from creative graduates in other subjects. Although both might end up in 'creative' occupations, the economic reward and working conditions of Bohemian graduates are far worse than those of other graduates. The fact that the labour market does not seem to value the work of the 'Bohemians' as much as other sub-groups of the 'creative class' poses the question to whether it makes sense to have a 'class' grouping all of them together or whether Bohemians might have a different role to society (mainly in the form of externalities).

Following from the initial findings and the theoretical framework developed in Comunian et al. (2010), the aim of the paper is twofold. Firstly, we analyse in detail the differences between subject sub-groups within the category of 'Bohemians', both in terms of career patterns and labour market performance. In fact, even within a seemingly homogenous group such as the 'artistic' part of the creative class, the differences are likely to be noticeable. However, while there is a wealth of work analysing certain artistic professions as separate 'case studies', there has not been so far a study comparing different creative subfields and their associated career patterns. Our unique data on UK graduates allows for such comparison.

Secondly, in discussing the career patterns of the different 'artistic' graduates, we also briefly present a picture of the geographical distribution of these graduates in the UK. While the importance of attracting creative workers in more peripheral regions has been recognised as a key factor for regional success (COMUNIAN and FAGGIAN, 2011; JAYNE, 2005) - and hence it has been promoted in various policy and academic discourses - the reality is that creative people tend to cluster in urban centres (FLORIDA, 2003; GLA, 2002) and it is very difficult to attract them to more rural areas (OLFERT and PARTRIDGE, 2011). This is true worldwide and even more so in the UK where London and the South East account for $57 \%$ of the creative workforce (KNELL and OAKLEY, 2007).

The paper is organized as follows. Section 2 introduces the theoretical and policy background for our study. Section 3 briefly describes the data and methodology used. 
Section 4 presents the results. Finally, Section 5 discusses the findings and concludes, including further possible future research avenues.

\section{Theories and concepts}

The paper brings together and explores two different disciplinary perspectives. Firstly, the creative class (FLORIDA, 2002) and human capital (BECKER, 1964) theories are considered in relation to local economy development. Secondly, the precarious working conditions of creative workers - emerging mainly in the social sciences - question the positive narrative surrounding the creative class and the creative industries. To reconcile these two opposite perspectives, the question of the diversity of creative occupations and opportunities available is explored, with particular reference to the experience of graduates.

The creative class theory (FLORIDA, 2002) has put some key professionals, labeled 'creative class', at the heart of local economic development. This 'creative class' encompasses a wide range of professionals, of which creative workers (called the 'super-creative core') are only a small proportion. The focus is here not on specific industries but on individuals, who have the ability of generating spillovers and innovation within specific regional or urban contexts (STOLARICK and FLORIDA, 2006). For Florida the possibility of creating new creative ideas is not confined to people having formal qualification but is instead linked to what they do professionally. However, critics of the theory (GLAESER, 2005) have highlighted the overlap and strong correlation between the 'creative class' and the well-known concept of human capital. If we focus on the creative workers specifically, this overlap is even stronger. A report by NESTA (2003) has highlighted how creative workers in the UK are a highly educated group (43\% having a tertiary qualification or higher degree compared with the average $16 \%$ of the total workforce).

Florida (2002) also suggests that the individuals belonging to the creative class benefit from higher economic rewards (in terms of wages). In fact, he points out that, even though the Creative Class represents only $30 \%$ of the USA workforce, they earn more than $50 \%$ percent of all wages and salaries.

These findings are in clear contrast with other literature - mainly in social studies - which looks at the specific work dynamics of various sub-sectors of the creative economy. Some studies, such as Banks (2006) on the case of Manchester, highlighted that creative workers seem to have a 'common perspective' towards their profession and career, which values more intrinsic rewards, non-instrumental motives, moral and ethical values rather than pure economic rewards (BANKS, 2006). The more detailed investigations on careers and working conditions of creative workers are normally restricted to the study of a specific sub-sector. For example, Kloosterman (2010) addresses the wage compromises of young architects in the Netherlands and their 'artistic logic of practice' (BOURDIEU, 1993, 1996) highlighting that these compromises (low wages, long hours) are often seen by young creative workers as a personal investment in the difficult process of learning their profession and pursuing the long-term objective of starting their own business.

Blair et al. (2001) exploring the film industry in UK highlights that 'long hours and structured job insecurity' (p.182) are the norm for all workers with no distinction between young or 
established workers. The 'boundary-less' careers (JONES, 1996) of the film sector present communalities with the careers patterns and strategies of designers. Vinodrai (2006), in her detailed analysis of the Toronto's design sector, shows that on-going collaborations and the importance of reputation are key elements of the career strategy of designers, which is based not only on project work but also around building partnerships and new companies. In an ever changing project-based landscape (GRABHER, 2004), such as the design world, precarious work conditions and career disruptions are the norm for most workers.

These patterns seem common to other sectors. Eikhof and Haunschild (2006), investigating the theatre sector in Germany, underline that another strategy to cope with precarious work is a blurred boundary between work and personal life, where a 'Bohemian' lifestyle becomes part of the identity of the creative worker. This seems to be taken to the extreme in the case of fine artists, who - as shown by Oakley (OAKLEY, 2009) - still closely identify themselves with a Romantic notion of "artist as truth teller" (p.281). The major contributions addressing different sectors of the creative industries are summarised in Table 1.

\section{> INSERT TABLE 1 HERE $<<$}

In general, all these studies acknowledge that creative labour is characterised by precarity, instability and low economic rewards (ROSS, 2003). Oakley (2009) considers the role of higher education in shaping the attitude of artists towards work, wondering whether the attitude towards 'sacrificial labour' (attitude towards accepting lower economic rewards and the emphasis on gratification coming from their practice) is in fact an acquired framework that is embedded in their training. Taylor and Littleton (2008) also point out that for students entering creative careers the relationship between making art and earning money is a "complex interplay" of new and old understanding of the role of artists "which may not easily be re-shaped as an adaptation to changing employment opportunities in the creative industries" (p.290).

These patterns have also emerged in the research on Bohemian graduates (ABREU et al., 2011; COMUNIAN et al., 2010), who are more likely to experience lower salaries, more parttime and freelance occupations and a lower percentage of graduate occupations compared to the rest of the graduates. However, no attention has been paid to the different disciplines and careers patterns of graduates in different disciplines within the broad 'Bohemian graduates' category. Building on initial work by Comunian et al. (2010) the current paper addresses this shortcoming by exploring the differences in labour market performance and career patterns across three sub-sectors of the Bohemian graduates: creative arts \& design graduates; creative media graduates and other creative graduates.

To reconcile the positive arguments presented in relation to the creative class and the precarious working conditions of creative workers, we need to consider that different creative workers might experience these dynamics with different intensity. These differences have not been addressed by the literature as the policy framework of the creative industries has now almost unanimously been accepted by academics and researcher, after initial criticisms and attacks (GALLOWAY and DUNLOP, 2006; GARNHAM, 2005). The literature tends to portrait the creative industries as a cohesive group of sectors with respect to economic and job dynamics. However, this is an underexplored issue and in 
fact some initial comparison on the economic performance of different creative sectors reveals interesting differences (CHAPAIN and COMUNIAN, 2009; COMUNIAN, 2009). Hence, the need to better explore what impact different sub-disciplinary courses and education choices might have on employability and career performance of Bohemian graduates.

The first attempt to address these issues directly can be found in a recent report by NESTA (2008b) which, using Labour Force Survey Data, highlights some of the differences in salary levels and employment patterns in the creative industries (as defined by the DCMS, see COMUNIAN et al. 2010). From the report it emerged, for instance, that self-employment is as low as $2 \%$ in the Software and Games sector and as high as $11 \%$ in the Music and Performing arts occupations.

The lack of comparative work is linked to difficulties in undertaking this kind of research due mainly to data availability. There is, however, a recognition that research of this kind is needed as working patterns of, say, an architect and a musician might be very different and almost opposite. While initial findings by Comunian et al. (2010) and Abreu et al. (2011) show that Bohemian graduates have generally 'unrewarded careers', some sub-disciplines might be better 'rewarded' by the labour market than others. In the present research, we consider the way the subjects undertaken at university might have an impact on the kind of career patterns and economic rewards that Bohemians might experience.

The literature exploring the diverse geography of the creative economy in UK is also quite limited and it refers almost exclusively to the location of firms and their employees. The first study who tried to map the size of the sector but also its geographical distribution was undertaken by Pratt (1997). In this first analysis, a clear dominance of London and the South East was identified with respectively $24 \%$ and $21 \%$ of Britain's cultural industries employment in 1991.

Since that first study, two DCMS documents $(1998,2001)$ and the Creative Industries Economic Estimates, the latest of which was published in 2010 (DCMS, 2010), have provided a national map of creative industries, although many have identified statistical problems and issues with the data collected (TAYLOR, 2006). However, the DCMS has conducted only national mapping exercises and has not addressed the geographical dimension of this growth and employment patterns (and the possible disparities). Other more precise maps have been created for specific local and regional contexts, but unfortunately the data have been collected adopting different definitions and frameworks hence not enabling meaningful regional comparisons (CHAPAIN and COMUNIAN, 2009) and giving a very fragmented picture of the sector.

Of all the UK regions, London seems to be the only location where employment patterns have been investigated more closely in the last decade. This is mainly due to the work of the Greater London Authority (GLA, 2002, 2004, 2007). A very provocative report with the title 'London's Creative Economy: An Accidental Success' was also produced by the London Development Agency in 2007 (Knell and Oakley, 2007). The GLA (2007) report highlights that London and the South East are estimated to include 57 per cent of all British creative workforce and that there is a high level of 'embeddedness' of creative occupations within the creative industries with only $31 \%$ of creative occupations outside the creative industries (compared to $52 \%$ for the rest of the UK). 
A more recent study by Clifton (2008) applies the Florida methodology to map the creative class in the UK using NUTS3 regions instead of local authority boundaries. As before, the creative class and Bohemians appear to be very unevenly spread, with London and the South East playing a dominant role.

Even more recently, a new study commissioned by NESTA (2009) identifies the main clusters of creative industries in UK. What is interesting for the purposes of our study is that the report maps not only the 'creative industries' as a whole, but also the sub-sectors within it. The main finding is that London has the largest concentration in six out of the nine creative sub-sectors, i.e. Advertising, Designer Fashion, Video, Film and Photography, Music and the Performing Arts, Publishing and Radio and TV (p. 18). However, three sub-sectors are highly concentrated outside the London area: Architecture shows higher concentration in Scotland and the North-East, Arts \& Antiques in the South West and Software, Computer Games and Electronic Publishing in the South East (and London is in second place).

Connecting with this geographical literature, our paper will provide a picture of the location of Bohemian graduates and test the relevance of London and the South East in producing, retaining and attracting them.

Our analysis is based on data from the 'Students in Higher Education' and the 'Destinations of Leaves from Higher Education' (DLHE) survey, both collected by the UK Higher Education Statistical Agency (HESA). The Students in Higher Education data contain individual student records with information on a series of variables including: personal characteristics (such as gender, age and ethnicity), subject of study (at the 4 digit Joint Academic Coding System (JACS ${ }^{i i)}$ code), mode (full time vs. part time) and level of study (e.g. postgraduate, undergraduate); degree results and institution attended. The DLHE survey is undertaken every year to collect information about graduates' employment six months after graduation and includes information on: salary level (for part time workers this is the full time equivalent), employer sector code (4-digit SIC code), job occupational code (4-digit SOC code), location of employment (postcode). The latter dataset is generally targeted towards British domiciled students; hence we concentrate on this group.

The British HEls can be grouped in different ways, one such way is to use a 4-category classification which includes: Russell group universities (compromising of 20 research intensive universities who receive the majority of research grant and contract income), other 'old' universities, 'new' universities (established as part of the abolition of the binary divide in 1992) and Higher Education/Further education colleges. The Russell group universities are generally considered to be more prestigious, followed by the other 'old' universities. This is a commonly used classification (Faggian and McCann, 2009a, 2009b; Faggian et al. 2007a, 2007b) and it is the one we adopt in this paper.

We focus on the cohort of students who graduated in 2005 (with employment data for 2006). As we are interested in employment patterns, these two years are particularly good as they refer to the pre-recession period. The recession which took place following the 2007 credit crunch in UK had a negative effect on graduates' employment in general (SHATTOCK, 
2010), but it might have impacted graduates from different disciplines differently hence biasing our results.

For the 2005 cohort, the student dataset includes 442,518 records of finalists (i.e. eligible for a DLHE return), from 168 HEls. The DLHE has information on 313,800 graduates, which equates to a $71 \%$ response rate. We will make use of both samples, using the finalists sample to examine where students study and the DLHE returns to examine employment patterns.

Advancing on the initial work by Comunian et al (2010), we explore further the 'Bohemian' graduates' category by identifying three sub-groups:

- Creative arts \& design graduates: all JACS codes starting with $\mathrm{W}^{\mathrm{iii}}$. They include: W100 Fine Arts (and sub-disciplines), W200 Design Studies (and sub-disciplines), W300 Music (and sub-disciplines), W400 Drama (and sub-disciplines), W500 Dance (and sub-disciplines), W600 Cinematics and Photography (and sub-disciplines), W700 Crafts (and sub-disciplines), W800 Imaginative Writing (and sub-disciplines), W900 Others in Creative Arts and Design.

- Creative media graduates: all JACS codes starting with $\mathrm{P}^{\mathrm{iv}}$. They include: P100 Information Services (and sub-disciplines), P200 Publicity Studies (and subdisciplines), P300 Media studies (and sub-disciplines), P400 Publishing (and subdisciplines), P500 Journalism (and sub-disciplines), P900 Others in Mass Communications and Documentation (and sub-disciplines).

- Other creative graduates: subjects mainly linked to technologies-based creative subjects and architecture. They include: G450 Multi-media Computing Science, G600 Software Engineering, G610 Software Design, J930 Audio Technology, J931Music Recording, P412 Publishing on CD-ROM, P413 Publishing via the World Wide Web, P420 Multi-media Publishing, P430 Interactive Publishing, W280 Interactive and Electronic Design, W615 Animation Techniques, K100 Architecture, K110 Architectural Design Theory, K120 Interior Architecture, K130 Architectural Technology, K190 Architecture not elsewhere classified, K300 Landscape Design, K310 Landscape Architecture, K320 Landscape studies, K390 Landscape Design not elsewhere classified;

As in previous investigations (Comunian et al. 2010 and Abreu et al. 2011) we base the definition of creative occupations on the DCMS definition (1998; 2001) which includes: Advertising, Architecture, Art and antiques markets, Computer and video games, Crafts, Design, Designer fashion, Film and video, Music, Performing arts, Publishing, Software, Television and radio. In a recent review of the sector, DCMS (2009, p. 9-11) provides the 4digit SIC codes used to define and estimate the size of the creative industries, supplemented with SOC codes for creative workers based in other sectors. Using a creative occupations approach à la Cunningham et al (2004) we consider both creative careers within the creative industries but also creative jobs in other sectors. Of the 442,518 finalist, $12.88 \%$ where identified as Bohemian graduates: $7.64 \%$ in creative arts \& design, 3.39\% in creative media and $1.85 \%$ other creative subjects. The distribution of bohemian graduates was similar for the 313,800 graduates with a DLHE return $(8.12 \%, 3.45 \%$ and $1.77 \%$ respectively). 
As highlighted in our literature review although prior studies have focussed on career patterns of Bohemian students and the fact they are generally unrewarded, few have explored the potential heterogeneity within these subjects, and at the same time, few studies have looked at the role played by geographical location in helping Bohemian students and graduates to be successful. This paper aims to address this gap in the literature by answering three core research questions:

1. What is the geography and $\mathrm{HE}$ institutional structure of Bohemian graduates?

2. Are there differences in career perform across non-bohemian and bohemian students and the three creative sub-groups: creative arts \& design graduates; creative media graduates; other creative graduates?

3. What is the role of subject studied and location of the first job in determining the type of job entered, the salary offered and the overall career success of Bohemian graduates and their sub-groups?

To answer the first question, we present some descriptive statistics, highlighting where students concentrate to study creative disciplines and what degree of specialisation can be identified between HEls, geography and Bohemian students. Secondly, in order to answer our second question, we present some descriptive statistics on the similarities and differences emerging in career patterns between non-Bohemian and Bohemian graduates, the latter also divided by disciplinary sub-groups. Finally, to answer our third question, we use the DLHE data to model differences in working mode (i.e. full-time, part-time, selfemployment and unpaid/voluntary work) and earnings across Bohemian graduates (and their sub-disciplines). We focus specifically on undergraduate students to be consistent with earlier work (COMUNIAN et al. 2010 and ABREU et al. 2011).

The modelling is done by means of a multinomial logit model (MNL) and Mincer-type wage regressions. In the MNL -with robust standard errors to control for heteroskedasticity- the categorical dependent variable is 'work mode' and takes four values: full-time, part-time, self-employment and unpaid/voluntary work.

Formally the MNL can be expressed as:

$\ln \left(\frac{P_{J}}{P_{B}}\right)=\beta_{J / B} X+\varepsilon$

$P_{J}$ refers to the probability of being in category $J$ and $P_{B}$ the probability of being in the base category (in our case full-time employment). $X$ is our set of explanatory variables and $\varepsilon$ is a random error term. The coefficient for each explanatory variable is to be interpreted relative to the base category. To make the beta coefficients more intuitive we calculate the relative risk ratio (RRR), as follows:

$\left(\frac{\mathrm{P}_{\mathrm{J}}}{\mathrm{P}_{\mathrm{B}}}\right)=\exp \left(\beta_{J}-\beta_{B}\right) X$ 
A RRR below 1 indicates that a variable negatively affects the probability of being in category J relative to the base category, and likewise a value above 1 indicates the variable positively affects this probability. We include as explanatory variables in our MNL model: gender, age, ethnicity, disability status, institution type, degree classification and region of employment (all dummy variables). We compare models for bohemian and non-bohemian students, with a final model looking specifically at those in creative jobs, where we include indicators of the creative sub-disciplines (relative to non-bohemian graduates).

One criticism of the MNL framework is that it relies on the independence of irrelevant alternatives (IIA) axiom. The IIA axiom states the ratio of the probability of two choices should not be altered by the inclusion of another alternative i.e. choices are independent of each other (for more on the IIA axiom see Train, 2003). Therefore it is important for a multinomial logit model to pass the IIA axiom, which can be tested by means of a Hausman test (Hausman and McFadden, 1984). Across our models the Hausman test provides no evidence that the IIA axiom is violated.

The Mincer-type earning equations are used to examine the salary determinants of Bohemian graduates and related sub-groups. Formally a Mincer wage equation takes the form:

$\ln W=\beta X+\varepsilon$

Where the dependent variable is the natural logarithm of earnings (W), $X$ is a vector of explanatory variables and $\varepsilon$ is a random error term. We include the same explanatory variables as in the MNL models plus job characteristics: whether graduates hold a 'creative' occupation, their work mode (part time, self employed/freelance vs. full time employment) plus their industry and occupation type. We firstly estimate a model for our entire sample with additional controls of the bohemian sub-disciplines (relative to non-bohemian graduates) and then compare salary models across Bohemian sub-disciplines.

\section{Results}

\subsection{Creative Higher Education and its geography}

Before considering the relevance of geography and creative sub-disciplines in the development of graduates' creative careers, we present a brief picture of the 'geography of creative higher education' in the UK, i.e. where students concentrate to study Bohemian disciplines and what kind of HEls offer courses in these disciplines (Table 2, part a).

\section{> INSERT TABLE 2 HERE $<<$}

The top two regions for bohemian students are Greater London (especially arts \& design and media students) and the South East. However, Yorkshire and the Humber, also figures prominently in other creative subjects ( $14.95 \%$ second after Greater London) and in creative media (10.19\% third after Greater London and the South East). Creative arts \& design 
students are also concentrated in the North West (11.05\%). London, South West and East Midlands are also regions where the share of bohemian students is higher than the share of non-bohemian students. This shows that, despite the dominant role of London and the South East, other regions do play a significant role in specific sub-disciplines.

A recent report commissioned by London Higher (LONDON HIGHER, 2005) suggests that "one of the special features of London's unique higher education landscape is the strong link between the capital's higher education institutions and businesses and agencies in the creative sector - whether through the depth and variety of related academic teaching and research, or through direct interaction with business and the community" (p.3). The interconnection between public policy, higher education and the creative economy has only partially been explored (COMUNIAN et al., forthcoming). Knell and Oakley (2007) point out that London HEls are a key part of the public infrastructure around the London creative economy. They suggest that HEls (like publicly supported cultural institutions) function as "R\&D lab, providing risk funding and an atmosphere of experimentation" (p.23) for the creative sector. They also see HEls as vital for the development of - often exclusive "tightly bound social networks" (p. 18). We can argue, however, that this might also be linked to the competitive advantage of London in the UK creative economy. The provision of creative courses is not only geographically clustered around London, it is also concentrated in certain types of HEls (Table 2, part b).

Colleges and New Universities cater for the vast majority of Bohemian courses, especially in the creative arts \& design sub-field. As shown by Comunian et al. (2010), the fact that most Bohemians study at Colleges and New Universities might have 'signalling' (à la SPENCE, 1973) implications and ultimately have a negative impact on their entry salary upon graduation.

\subsection{Bohemian graduates and creative sub-disciplines: exploring similarities and differences}

As suggested by other literature in the field (ABREU et al., 2011; ASTON, 1999) Bohemian graduates experience different career patterns than the rest of the graduates. Part-time, freelance work and higher levels of unemployment are a common pattern. This is further confirmed by our data (Table 3). Bohemian graduates are less likely to enter full-time paid work and unemployment is also higher.

\section{> INSERT TABLE 3 HERE $<<$}

What is interesting, however, is that different patterns emerge between the three subdisciplines. While creative arts \& design graduates experience comparatively low level of full-time paid work, both creative media graduates and other creative graduates experience relatively high levels of full-time paid work, with the creative media graduates actually showing a percentage even higher than the Non-bohemian group (59.01\% vs. $57.39 \%$ ). Differences are also significant in part-time and voluntary/unpaid work. Part-time work is higher for creative arts \& design graduates (11.56\%) and creative media $(10.28 \%)$ but is very low (even lower than the Non-bohemian group) for other creative graduates (6.29\%). The same holds for voluntary/unpaid work. 
Work patterns might also be related to the sector graduates enter into and particularly to whether Bohemians enter a creative or a non-creative occupation. Previous studies have found that a very high percentage of Bohemian graduates do enter a 'creative' occupation and that this is true not only in the short-term (COMUNIAN et al. 2010) but also in the medium-long term (ABREU et al. 2011). We acknowledge that often graduates might find rewarding job opportunities in occupations different from the subject they studied. However, after investing three (and more) years of their life in specializing and studying a specific discipline, it seems that the most rewarding - not in only in salary terms but also in reference to fulfilment and job satisfaction - occupation for students should be one close to their creative studies.

The irregular career patterns of Bohemians are also reflected in their entry salaries (Table 4).

\section{> INSERT TABLE 4 HERE $<<$}

Non-bohemian students earn, on average, $£ 4,000$ more than Bohemians both within and outside creative occupations. However, interesting differences emerge again between the sub-groups of Bohemian graduates. Creative arts \& design graduates are the ones with the lowest average salaries irrespective of whether they enter a creative or non creative occupation. On the opposite, both creative media and other creative graduates seem to be better off if they find a creative job (with a difference in the median salaries of about $f$ 2,000 ). In general, the other creative graduates group is the one performing the best in terms of salaries, especially if entering a creative occupation with a difference of only $£ 1,000$ in the median salary compared to Non-bohemians.

4.3 Does geography matters for Bohemian graduates? An analysis of working patterns and salary levels

Table 5 presents the results of the MNL model in 'relative risk rations' (RRR) terms, as outlined in section 3 .

\section{> INSERT TABLE 5 HERE $<<$}

The first two models in Table 5 (Columns 1-6) show the effect of job location on the probability of finding a part-time, freelance or unpaid/voluntary work for Non-bohemians and Bohemians respectively after controlling for a series of personal and degree characteristics of graduates.

Before discussing the results on location, it is worth mentioning a few interesting results on the control variables. Being female increases the chances of getting a part-time or unpaid/voluntary job, but reduces the likelihood of being self-employed especially for Nonbohemians. This is in line with most labour market literature. Age affects the probability of having a full-time job as expected, i.e. older graduates are more likely to find a full-time job than part-time or unpaid. However, they are also more likely to become self-employed. Ethnic minorities are also more likely to work part-time or in unpaid/voluntary jobs. 
As for the degree variables, it is interesting to notice that graduating with a first degree classification (the highest mark in the $\mathrm{UK}^{\mathrm{V}}$ ) makes Non-bohemians less likely to work parttime, while it makes Bohemians more likely to be freelance or self-employed. One possible explanation might be that first-class graduates in Bohemian subjects have a more creative or interesting portfolio, which might therefore make it easier for them to get employed on a freelance base. Both among the Non-bohemians and the Bohemians, the 'signal' derived from graduating from a Russell Group university increases the chances of getting a full-time job.

As for the location of jobs, London is clearly associated with higher chances of full-time work for both Bohemians and Non-bohemians. However, while Non-bohemians are less likely to enter unpaid/voluntary jobs in London, Bohemians are about $27 \%$ more likely to enter voluntary/unpaid work in London than elsewhere. This might be part of their 'portfolio building' strategy. Internship and unpaid work experiences in high-end organizations and companies could be more important for Bohemians than other graduates. McRobbie (2002) suggests that, in fact, unpaid work is a common practice for creative workers. As for the other regions, Bohemians are most likely to enter part-time work in the North East of England or outside England (in order Wales, Scotland and Northern Ireland). Nonbohemians are more likely to be part-time in Northern Ireland and Scotland followed by the North East of England and Wales. Self-employment is more likely in the South East (the base category) than in the rest of the country.

Model 3 in Table 5 (Columns 7-9) looks specifically at graduates in creative occupations and controls also for the three sub-groups of Bohemian graduates (i.e. creative arts $\&$ design, creative media and other creative). Most of the results are in line with models 1 and 2, but few differences are worth mentioning. For graduates working in creative occupations holding a degree from a Russell group university actually increases their chances of being self-employed or being in a part-time or voluntary/unpaid job. This highlights that the creative sector is structurally different than the rest of the economy - with more projectbased work and part-time freelance opportunities - and even graduates from the most prestigious HEls have this kind of jobs (often holding more than one job).

As for the sub-disciplines studied, graduates in creative arts \& design are the most likely to work part-time, be self-employed or freelance (over 6 times more likely), or have an unpaid/voluntary job. Creative media graduates are also less likely to be full-time, even though not as much as creative arts \& design graduates. Other creative graduates, however, are not very different from the Non-bohemians graduates and, in fact, they are less likely (by $40 \%$ ) to be part-timers.

Finally, the geographical patterns are similar to models 1 and 2, except that now the regional discrepancies seem larger, e.g. graduates in the North-East and Wales working specifically in creative occupations are now more than twice as likely to be part-timers. Unpaid/voluntary work is now $35 \%$ more likely in London, while self-employment is about $30 \%$ less likely.

In section 4.1 we saw how Bohemian graduates have a salary disadvantage. However, we did not simultaneously control for other factors. In order to do so and have a better idea of the salary determinants, we estimated earning functions à la Mincer with the logarithm of 
nominal salaries as dependent variable, and controls for personal, degree and job characteristics. The results of the OLS estimations, with robust standard errors to control for heteroskedasticity, are reported in Table 6.

\section{> INSERT TABLE 6 HERE $<<$}

The models confirm some of our preliminary observations derived from the descriptive statistics. Female graduates earn on average $4.4 \%$ less than men. The highest gender gap is for other creative graduates (8.2\%), followed by creative arts \& design graduates (with a gap of $5.4 \%$ ). There is no significant gender difference for creative media graduates. Age (as a proxy for experience) has, as expected, a positive impact on all graduates' salary even though not as much for the creative arts \& design and creative media graduates. While ethnicity has a negative influence on the salary of non-creative graduates, it is not significant (or even positive) for the three creative sub-groups.

The degree classification - in particular getting a 'first' - has a positive effect (about $2 \%$ ) in the general graduate population and for the Non-bohemian group and a very strong positive effect for other creative graduates (5.8\%), but does not affect the salary of creative arts \& design and creative media graduates. This is in line with the literature that suggests that for these graduates formal qualifications (and their level) are far less important than their portfolio (Ball, 2003). Similarly, the 'signaling' effect derived from the kind of HEl attended is insignificant for Bohemian graduates while positive and significant for Non-bohemians (a graduate from a Russell Group university has on average an entry salary 4\% higher). However, creative arts \& design graduates from HE/FE colleges earn about $5 \%$ less than graduates from other HEls.

Having a creative job does not have strong bearing on the salary of Bohemians once all the other factors have been controlled for. Being in a part-time job is obviously related to lower salaries especially for creative arts \& design graduates (minus $41 \%$ ). Freelancing and selfemployment are associated with lower salaries only for creative arts \& design graduates, but has no effect for the rest of the graduate population suggesting that this kind of jobs can actually be as remunerative, on average, as a full-time job.

Looking at the impact of regions of work on salaries, London, as expected, has an average salary advantage of about $14 \%$. Within the Bohemians sub-groups, however, creative arts \& design graduates only benefit from a $10 \%$ salary advantage ( $4 \%$ lower than the average). If we also consider the higher cost of living of the capital, this $10 \%$ difference in nominal salaries means that graduates in London are not better off, in economic terms, than their colleagues employed in more peripheral regions. However, especially for Bohemians, the 'buzz' of global cities - like London - seems is vital for networking and inspiration and therefore for better longer term job perspectives (COMUNIAN, 2011; CURRID, 2007). Sunley et al. (2010), for instance, in relation to the design sector, argue that "there is a perception among the most ambitious design graduates that succeeding in the industry demands moving to London"(p. 878).

In most of the 'peripheral' regions, including Scotland, Northern Ireland, the North West, Yorkshire and Humber and the South West, the other creative graduates seem to be the most disadvantaged, while creative media graduates are not significantly different from the 
general graduate population, with the only exception of those working in the North of England.

\section{Conclusions, policy implications and future research}

This first exploration of the diversity of skills and professionalism of Bohemian graduates, as well as their diverse economic rewards, has highlighted the need for a better understanding of creative skills and creative labour markets. In particular, it seems that broader policy and academic frameworks, such as the creative industries in UK and the creative class in USA do not allow a fine-grain understanding of the labour dynamics and career patterns experienced by graduates entering the creative economy.

While different disciplinary and professional groups experience common employment dynamics, such as project-based and freelance work, the relevance and importance of these patterns seem to be very different across the creative industries spectrum. The paper exposes initial comparative differences and call for more research to focus on the specificities of each sector and its labour market. This is particularly important in policy term, as training, support and policy initiative that target the sector as a whole might miss out opportunities for more targeted and potentially more relevant interventions towards specific sub-sectors of the creative economy labour markets.

The results emerging from our analysis seem to suggest that sub-disciplines within the Bohemian graduates group matter in reference to the possibility for students to enter creative occupations and be rewarded economically for their work. In particular, our findings suggest that the 'creative arts and design' group is the most vulnerable in the labour market (in contractual terms and also in reference to earnings). On the other hand, creative media and other creative graduates seem to experience a better job prospective.

We find that this resonates with the employment trends presented by the latest DCMS statistics (2010), which shows that sectors like Software, Computer Games \& Electronic Publishing and Architecture have enjoyed the largest employment growth in the period 1997-2008 amongst all creative industries sub-sectors (respectively $5 \%$ and $3 \%$ ). While other subsectors, like Video, Film \& Photography or Radio and TV have not grown at all. In the same period, employment in Publishing has been shrinking (-2\%). These numbers suggest that while policy makers have been actively promoting the creative economy as a whole and this has resulted in more student entering HEls with the vision of finding a job in the creative industries, the overall balance between labour supply and demand is very patchy.

Our data seem to also reflect a general policy trend away from a generic creative Industries/creative economy framework, strongly promoted soon after the New Labour came to power in 1997 (DCMS, 1999a, b, 2001, 2003) towards investment and promotion of the media and technological sub-sectors of the creative industries, i.e. the new 'Digital Britain' (DCMS and BIS, 2009).

Following this first investigation, we identified at least three critical issues and venues for future research: 
- While the broader literature suggests that creativity plays a role in economic development, our results suggest that Bohemian graduates are not rewarded in the labour market, especially in certain sub-disciplines, such as creative arts and design. On the opposite, 'media and technological' creativity is better rewarded and provides more opportunities for graduates to enter creative and remunerative occupations. Also Boschma and Fritsch (2009) identify some limitations in the current research and point out that more "studies are needed that account for all three types of creativity [...] creativity in the artistic, technological (innovation) and economic (entrepreneurship) sphere [...] Such studies should also try to better understand the relationship between creativity and education" (BOSCHMA and FRITSCH, 2009, p.418). In particular, the differences emerging across the sub-sectors in our analysis highlight the need for a finegrained understanding of the creative industries. A more detailed understanding of different components of the creative industries might also result in opportunities for more targeted policies.

- Bohemian graduates seem to be penalised in the labour market. This could be linked either to the kind of signal that different HEls provide to the employers (signalling theory) or to the kind of skills that these creative courses provide (human capital theory). Sunley et al. (2010), looking at the design sector in UK, report that their interviewees often found difficult to recruit good quality graduates "as more and more students have entered design courses, the quality of which has been reduced. While there is an oversupply of design graduates, few of these have the necessary drawing, analytical, and business skills" (p. 878). There are therefore hints to the possibility that these graduates enter the labour market not equipped with the right kind of skills and companies become "wary about taking on graduates as they believed they would require large amounts of mentoring and training from experienced colleagues" (SUNLEY et al. 2010, p.878). Similarly Ball (2003) suggests that in their transition to work, graduates in these disciplines have "poor professional, personal and career management skills, such as networking, research skills and ability to research and access information that will be helpful to them in their future careers" (p.16). This lack of adequate "human capital' might be one of the explanations for the lower salary level of Bohemians and it is worth further investigation in the future.

- Finally, the relationship between policy and the creative economy needs to be better explored (COMUNIAN et al., 2011). While the broader definition of 'creative industries' has generated numerous headlines, it seems that economic growth is not common to all the creative industries but only to few (mainly technology based) industries, as suggested in Comunian (2009). This might have strong policy implications for the new UK coalition government where arts, culture and media could go back into a more 'art's for art's sake' discourse, while the new Digital Britain agenda - and the more business and technological oriented creative industries - are taken forward by a different framework in the Department for Business, Innovation \& Skills. The first speech of the Secretary of State for Culture suggests a move away from the New Labour rhetoric that culture and economic goals can work together in public policy terms "when I was watching Jerusalem - I wasn't thinking about creative exports or leveraged investment. I was enjoying artistic excellence. Art for art's sake. That is my starting point as Secretary of State for Culture" ${ }^{\mathrm{vi}}$. This might also have strong implications in the Higher Education and skills framework development around these industries. 


\section{Acknowledgements}

We acknowledge the support of the "Impact of Higher Education Institutions on Regional Economies Initiative" (ESRC grant number RES-171-25-0032 co-funded by HEFCE, Scottish Funding Council, HEFCW and DELNI). Nevertheless, all views expressed are solely the responsibility of the authors. 
Tables

Table 1: Summary of major studies of creative occupations in different sectors of the creative economy

\begin{tabular}{ll}
\hline Sector & \multicolumn{1}{c}{ Literature } \\
\hline Fashion Design & (MCROBBIE, 2002) \\
Design & (REIMER et al., 2008; SUNLEY et al., 2010; VINODRAI, 2006) \\
Music & (HRACS, 2009; JUUTI and LITTLETON, forthcoming; LORENZEN and \\
& FREDERIKSEN, 2005) \\
\hline Film \& Television & (BLAIR, 2001; BLAIR et al., 2001; HESMONDHALGH and BAKER, 2008) \\
\hline Theatre / Performing Arts & (EIKHOF and HAUNSCHILD, 2006; FREAKLEY and NEELANDS, 2003) \\
Fine Art & (BAINES and WHEELOCK, 2003; NESTA, 2008a; OAKLEY, 2009; \\
& TAYLOR and LITTLETON, 2008) \\
Advertising / Publishing & (CREWE, 1996; EKINSMYTH, 2002; NIXON and CREWE, 2004) \\
New media & (GILL, 2002; NEFF, 2004) \\
Architecture & (KLOOSTERMAN, 2010) \\
Craft Makers & (MCAULEY and FILLIS, 2005) \\
\hline
\end{tabular}


Table 2: Bohemian students by region of study and HEI Type

\begin{tabular}{|c|c|c|c|c|c|c|}
\hline & \multirow[t]{2}{*}{ Total Graduates } & \multirow{2}{*}{$\begin{array}{c}\text { \% Bohemian } \\
\text { Graduates }\end{array}$} & \multirow{3}{*}{$\begin{array}{c}\% \text { Creative arts \& } \\
\text { design }\end{array}$} & \multirow[b]{2}{*}{$\%$ Creative media } & \multirow[b]{2}{*}{$\%$ Other creative } & \multirow{2}{*}{$\begin{array}{c}\% \text { Non-Bohemian } \\
\text { Graduates }\end{array}$} \\
\hline & & & & & & \\
\hline a) Region & & & & & & \\
\hline Greater London & 70,187 & 22.13 & 22.89 & 20.28 & 22.43 & 14.93 \\
\hline South East & 61,633 & 13.41 & 13.13 & 14.20 & 13.15 & 14.00 \\
\hline North West & 47,205 & 9.87 & 11.05 & 8.82 & 6.93 & 10.79 \\
\hline South West & 30,996 & 9.2 & 9.26 & 9.57 & 8.25 & 6.68 \\
\hline East Midlands & 35,352 & 9.16 & 9.39 & 9.87 & 6.87 & 7.82 \\
\hline $\begin{array}{l}\text { Yorkshire \& the } \\
\text { Humber }\end{array}$ & 40,358 & 9.03 & 7.07 & 10.19 & 14.95 & 9.13 \\
\hline Scotland & 42,524 & 6.82 & 5.32 & 7.26 & 12.24 & 10.02 \\
\hline West Midlands & 35,018 & 6.45 & 7.02 & 6.42 & 4.13 & 8.13 \\
\hline Wales & 26,345 & 5.85 & 5.81 & 6.22 & 5.35 & 5.97 \\
\hline East of England & 21,551 & 3.39 & 3.60 & 3.51 & 2.31 & 4.70 \\
\hline North East & 20,058 & 3.35 & 4.56 & 1.72 & 1.33 & 5.10 \\
\hline Northern Ireland & 11,291 & 1.34 & 0.89 & 1.95 & 2.06 & 2.73 \\
\hline \multicolumn{7}{|l|}{ b) HEI Type } \\
\hline Russell Group & 98,783 & 8.92 & 7.13 & 8.88 & 16.36 & 24.30 \\
\hline Other 'Old' & 114,700 & 14.00 & 13.12 & 16.47 & 13.12 & 27.68 \\
\hline New & 183,807 & 55.29 & 53.57 & 55.99 & 61.14 & 39.50 \\
\hline Colleges & 45,228 & 21.79 & 26.19 & 18.66 & 9.38 & 8.51 \\
\hline
\end{tabular}

Source: Our elaborations on HESA data 
Table 3: Work patterns for Bohemian and Non-bohemian graduates

\begin{tabular}{lccccc}
\hline Destination & $\begin{array}{c}\text { Non- } \\
\text { bohemians } \\
(\%)\end{array}$ & $\begin{array}{c}\text { Bohemians } \\
\text { graduates } \\
(\%)\end{array}$ & $\begin{array}{c}\text { Creative } \\
\text { arts \& } \\
\text { design } \\
(\%)\end{array}$ & $\begin{array}{c}\text { Creative } \\
\text { media } \\
(\%)\end{array}$ & $\begin{array}{c}\text { Other } \\
\text { creative } \\
(\%)\end{array}$ \\
\hline Full-time paid work & 57.39 & 53.77 & 51.37 & 59.01 & 55.00 \\
\hline Part-time paid work & 7.19 & 10.53 & 11.56 & 10.28 & 6.29 \\
Voluntary/Unpaid work & 0.67 & 0.96 & 1.07 & 0.93 & 0.56 \\
Work and Study & 10.37 & 7.70 & 7.67 & 6.01 & 11.13 \\
Further study only & 12.51 & 11.18 & 12.24 & 7.79 & 12.91 \\
Assumed to be unemployed & 4.72 & 7.63 & 7.75 & 7.75 & 6.83 \\
Not available for & 4.06 & 4.07 & 3.93 & 4.57 & 3.76 \\
employment & 0.97 & 1.61 & 1.74 & 1.48 & 1.29 \\
Other & 2.12 & 2.55 & 2.68 & 2.18 & 2.71 \\
Explicit refusal & & & & & \\
\hline No of obs. & 271,917 & 41,883 & 25,491 & 10,830 & 5,562 \\
\hline
\end{tabular}


Table 4: Mean (and Median) salaries by subject studied and occupation

\begin{tabular}{|c|c|c|c|}
\hline \multirow[t]{2}{*}{ Subject } & \multicolumn{3}{|c|}{ Mean (median) Salary } \\
\hline & Non creative occupation & Creative occupations & All (rows) \\
\hline \multirow[t]{2}{*}{ Non-bohemians } & 20,963 & 21,413 & 20,995 \\
\hline & $(19,000)$ & $(19,000)$ & $(19,000)$ \\
\hline \multirow[t]{2}{*}{ Bohemians } & 15,782 & 16,938 & 16,210 \\
\hline & $(15,000)$ & $(16,000)$ & $(15,000)$ \\
\hline \multirow[t]{2}{*}{ Creative arts \& design } & 15,460 & 15,698 & 15,530 \\
\hline & $(15,000)$ & $(15,000)$ & $(15,000)$ \\
\hline \multirow[t]{2}{*}{ Creative media } & 15,790 & 16,738 & 16,166 \\
\hline & $(14,000)$ & $(16,000)$ & $(15,000)$ \\
\hline \multirow[t]{2}{*}{ Other creative } & 17,899 & 19,493 & 18,856 \\
\hline & $(16,000)$ & $(18,000)$ & $(18,000)$ \\
\hline \multirow[t]{2}{*}{ Total } & 20,581 & 19,734 & 20,493 \\
\hline & $(19,000)$ & $(18,000)$ & $(19,000)$ \\
\hline
\end{tabular}


Table 5: Multinomial logit model of 'mode of work' for Non-bohemians, Bohemians and graduates in creative jobs (ref. category: full-time)

\begin{tabular}{|c|c|c|c|c|c|c|c|c|c|}
\hline \multirow[b]{2}{*}{$\begin{array}{l}\text { Dep.: mode } \\
\text { of work }\end{array}$} & \multicolumn{3}{|c|}{ Non-bohemians } & \multicolumn{3}{|c|}{ Bohemians } & \multicolumn{3}{|c|}{ Creative jobs } \\
\hline & Part time & $\begin{array}{l}\text { Freelance/ } \\
\text { self empl. }\end{array}$ & $\begin{array}{l}\text { Unpaid/ } \\
\text { voluntary }\end{array}$ & Part time & $\begin{array}{l}\text { Freelance/ } \\
\text { self empl. }\end{array}$ & $\begin{array}{l}\text { Unpaid/ } \\
\text { voluntary }\end{array}$ & Part time & $\begin{array}{l}\text { Freelance/ } \\
\text { self empl. }\end{array}$ & $\begin{array}{l}\text { Unpaid/ } \\
\text { voluntary }\end{array}$ \\
\hline \multicolumn{10}{|c|}{ Personal Characteristics } \\
\hline \multirow[t]{2}{*}{ Female } & $1.259 * * *$ & $0.398 * * *$ & $1.256 * * *$ & $1.129 * * *$ & $0.691 * * *$ & $1.315^{* *}$ & 1.072 & $0.667 * * *$ & $1.431 * * *$ \\
\hline & [12.7] & {$[-20.0]$} & {$[4.30]$} & [3.35] & {$[-7.73]$} & {$[2.55]$} & {$[1.18]$} & {$[-8.38]$} & {$[3.45]$} \\
\hline \multicolumn{10}{|c|}{ Age on graduation (ref: 21 and under) } \\
\hline \multirow[t]{2}{*}{$22-24$} & $0.710 * * *$ & $1.145^{*}$ & $0.800 * * *$ & 1.001 & $1.662 * * *$ & 1.242 & $0.813^{* * *}$ & $1.239 * * *$ & 1.026 \\
\hline & {$[-14.8]$} & [1.91] & {$[-3.47]$} & {$[0.021]$} & {$[6.42]$} & [1.51] & {$[-2.73]$} & {$[2.82]$} & {$[0.19]$} \\
\hline \multirow[t]{2}{*}{$25+$} & $0.943^{* *}$ & $2.441 * * *$ & 0.886 & $1.349 * * *$ & $4.116 * * *$ & 1.203 & $1.303^{* * *}$ & $2.999 * * *$ & 1.005 \\
\hline & {$[-2.15]$} & [11.7] & {$[-1.45]$} & [4.94] & {$[16.2]$} & {$[0.96]$} & [2.67] & {$[12.6]$} & [0.024] \\
\hline \multirow[t]{2}{*}{ Disabled } & $1.183^{* * *}$ & $1.561 * * *$ & $1.720 * * *$ & $1.284^{* * *}$ & $1.536 * * *$ & $1.825^{* * *}$ & $1.290 * * *$ & $1.391 * * *$ & $1.575^{* * *}$ \\
\hline & [4.83] & {$[6.00]$} & [6.32] & {$[4.60]$} & {$[6.40]$} & [4.31] & {$[2.72]$} & {$[4.55]$} & [2.99] \\
\hline \multicolumn{10}{|c|}{ Ethnicity (ref: white) } \\
\hline \multirow[t]{2}{*}{ Black } & $1.888 * * *$ & 0.838 & $2.186 * * *$ & $2.488 * * *$ & 1.241 & $2.069 * * *$ & $2.932 * * *$ & $1.958 * * *$ & $1.750 * *$ \\
\hline & [13.3] & {$[-1.28]$} & {$[6.20]$} & [9.45] & [1.44] & [3.09] & [6.79] & {$[4.45]$} & [1.99] \\
\hline Asian & {$[16.0]$} & {$[0.74]$} & {$[6.76]$} & {$[6.72]$} & {$[-0.53]$} & {$[2.38]$} & [3.67] & {$[0.10]$} & {$[1.40]$} \\
\hline \multirow[t]{2}{*}{ Mixed } & 1.106 & 1.102 & $1.502 * *$ & 0.997 & $1.441^{*}$ & $1.845^{*}$ & 1.314 & 1.199 & 1.154 \\
\hline & {$[1.08]$} & {$[0.44]$} & [1.97] & {$[-0.017]$} & [1.89] & {$[1.76]$} & {$[1.12]$} & {$[0.84]$} & {$[0.37]$} \\
\hline \multirow[t]{2}{*}{ Other } & $1.767 * * *$ & 1.139 & $2.586 * * *$ & $2.127^{* * *}$ & 1.244 & 1.152 & $2.669 * * *$ & $1.637^{*}$ & 1.692 \\
\hline & [5.89] & {$[0.53]$} & {$[4.40]$} & [3.80] & {$[0.79]$} & {$[0.24]$} & [3.72] & {$[1.82]$} & {$[1.12]$} \\
\hline \multicolumn{10}{|c|}{ Degree Classification (ref: Upper second) } \\
\hline \multirow[t]{2}{*}{ First } & $0.939 * *$ & 1.079 & 1.082 & 1.084 & $1.607 * * *$ & 1.202 & $0.860 *$ & $1.187^{* * *}$ & 0.893 \\
\hline & {$[-1.98]$} & [1.06] & [1.01] & [1.35] & [7.07] & [1.11] & {$[-1.66]$} & {$[2.60]$} & {$[-0.75]$} \\
\hline \multirow[t]{2}{*}{ Lower second } & $1.094^{* * *}$ & 0.973 & $0.901 *$ & 0.967 & $0.670 * * *$ & 0.9 & $1.145^{* *}$ & $0.902 *$ & 1.036 \\
\hline & [4.43] & {$[-0.52]$} & {$[-1.73]$} & {$[-0.85]$} & {$[-6.85]$} & {$[-0.87]$} & [2.03] & {$[-1.71]$} & {$[0.29]$} \\
\hline \multirow[t]{2}{*}{ Third/pass } & $1.201 * * *$ & $1.272 * * *$ & $0.731^{* *}$ & $1.170 * *$ & $0.579 * * *$ & 1.212 & $1.335^{* *}$ & 0.866 & 1.279 \\
\hline & [4.98] & [2.83] & {$[-2.37]$} & [1.96] & {$[-4.07]$} & [0.83] & [2.11] & {$[-1.07]$} & [0.94] \\
\hline \multirow{2}{*}{$\begin{array}{l}\text { Other degree } \\
\text { class }\end{array}$} & $0.565^{* * *}$ & $0.621^{* * *}$ & $0.239 * * *$ & $0.759 * *$ & 0.984 & 0.728 & $0.638 * *$ & 1.032 & $0.203^{* *}$ \\
\hline & {$[-15.1]$} & {$[-4.72]$} & {$[-8.63]$} & {$[-2.37]$} & {$[-0.11]$} & {$[-0.77]$} & {$[-2.33]$} & {$[0.23]$} & {$[-2.17]$} \\
\hline
\end{tabular}




\begin{tabular}{|c|c|c|c|c|c|c|c|c|c|}
\hline \multirow[t]{2}{*}{ Russell group } & $0.762 * * *$ & $0.784 * * *$ & $2.213 * * *$ & $0.776 * * *$ & $0.714 * * *$ & 1.166 & $1.453 * * *$ & $1.177^{* *}$ & $2.473 * * *$ \\
\hline & [-11.0] & {$[-3.87]$} & [11.7] & {$[-3.44]$} & {$[-3.03]$} & {$[0.77]$} & [4.37] & [2.04] & [6.53] \\
\hline \multirow[t]{2}{*}{ Other old } & $0.935^{* * *}$ & $0.852 * * *$ & $1.828 * * *$ & 1.022 & 1.035 & $1.499 * * *$ & $1.396 * * *$ & 1.062 & $1.992 * * *$ \\
\hline & {$[-2.96]$} & {$[-2.69]$} & [8.71] & [0.39] & {$[0.44]$} & {$[2.70]$} & [4.24] & {$[0.86]$} & [4.96] \\
\hline \multirow[t]{2}{*}{ HE/FE Colleges } & $1.207 * * *$ & $1.323^{* * *}$ & 1.039 & $1.138 * * *$ & $1.571 * * *$ & 1.223 & $1.390 * * *$ & $1.610 * * *$ & $1.339 *$ \\
\hline & {$[6.25]$} & [3.79] & [0.33] & [2.89] & {$[8.15]$} & [1.55] & [3.75] & [7.47] & [1.80] \\
\hline \multicolumn{10}{|c|}{ Creative Graduate Type (ref: Non-creative) } \\
\hline \multirow[t]{2}{*}{$\begin{array}{l}\text { Creative art \& } \\
\text { design }\end{array}$} & & & & & & & $2.572 * * *$ & $6.548 * * *$ & $2.657 * * *$ \\
\hline & & & & & & & [13.2] & [31.6] & [7.98] \\
\hline \multirow[t]{2}{*}{$\begin{array}{l}\text { Creative } \\
\text { media }\end{array}$} & & & & & & & $1.474^{* * *}$ & $2.320 * * *$ & $1.927 * * *$ \\
\hline & & & & & & & [3.98] & [10.1] & [4.18] \\
\hline \multirow[t]{2}{*}{ Other creative } & & & & & & & $0.693 * * *$ & 0.943 & 0.653 \\
\hline & & & & & & & {$[-2.76]$} & {$[-0.53]$} & {$[-1.57]$} \\
\hline \multicolumn{10}{|c|}{ Region of Job (ref: South East) } \\
\hline North East & {$[8.24]$} & {$[-3.30]$} & {$[-5.83]$} & [6.37] & {$[-0.69]$} & {$[-1.50]$} & {$[4.78]$} & {$[-1.07]$} & {$[-1.63]$} \\
\hline \multirow[t]{2}{*}{ North West } & $1.256 * * *$ & $0.724 * * *$ & $0.344 * * *$ & $1.143^{*}$ & $0.707 * * *$ & $0.582 * *$ & $1.429 * * *$ & $0.728 * * *$ & $0.495 * * *$ \\
\hline & {$[6.68]$} & {$[-3.62]$} & [-9.57] & [1.90] & [-3.59] & {$[-2.50]$} & [3.10] & {$[-3.16]$} & {$[-2.76]$} \\
\hline \multirow{2}{*}{$\begin{array}{l}\text { Yorkshire \& } \\
\text { Humberside }\end{array}$} & $1.179 * * *$ & $0.808 * *$ & $0.383 * * *$ & $1.196 * *$ & $0.574 * * *$ & $0.498 * * *$ & $1.331^{* *}$ & $0.800 *$ & $0.504 * *$ \\
\hline & [4.33] & {$[-2.24]$} & {$[-8.10]$} & [2.32] & {$[-4.72]$} & {$[-2.65]$} & [2.17] & {$[-1.96]$} & {$[-2.33]$} \\
\hline \multirow[t]{2}{*}{ East Midlands } & 1.018 & $0.821^{*}$ & $0.399 * * *$ & 0.993 & $0.473 * * *$ & $0.215^{* * *}$ & 1.096 & $0.635 * * *$ & $0.326 * * *$ \\
\hline & {$[0.41]$} & {$[-1.90]$} & [-6.83] & {$[-0.084]$} & [-5.59] & [-3.89] & {$[0.60]$} & {$[-3.50]$} & {$[-2.81]$} \\
\hline \multirow{2}{*}{$\begin{array}{l}\text { West } \\
\text { Midlands }\end{array}$} & $1.164^{* * *}$ & $0.747^{* * *}$ & $0.451 * * *$ & $1.460 * * *$ & $0.729 * * *$ & $0.389 * * *$ & $1.409 * * *$ & $0.812^{*}$ & $0.356 * * *$ \\
\hline & [3.99] & {$[-2.95]$} & {$[-6.97]$} & {$[5.02]$} & {$[-2.85]$} & {$[-3.12]$} & [2.59] & {$[-1.83]$} & {$[-2.92]$} \\
\hline \multirow[t]{2}{*}{ East } & 1.01 & 0.933 & $0.333^{* * *}$ & $1.152 *$ & $0.722 * * *$ & $0.424 * * *$ & 1.223 & $0.768^{* *}$ & $0.584^{*}$ \\
\hline & {$[0.23]$} & {$[-0.71]$} & [-7.93] & [1.71] & {$[-2.85]$} & {$[-2.87]$} & [1.47] & {$[-2.30]$} & {$[-1.95]$} \\
\hline $\begin{array}{l}\text { Greater } \\
\text { London }\end{array}$ & $0.912^{* * *}$ & 1.054 & $0.697^{* * *}$ & $0.859 * * *$ & 0.974 & $1.272 *$ & $0.861 *$ & $0.680 * * *$ & $1.354 * *$ \\
\hline South West & [1.34] & [-1.09] & {$[-7.10]$} & {$[-0.62]$} & [-3.92] & {$[-3.00]$} & {$[-0.062]$} & {$[-2.41]$} & {$[-3.28]$} \\
\hline Wales & $1.421 * * *$ & 0.827 & $0.459 * * *$ & $1.745^{* * *}$ & 0.91 & $0.403^{* *}$ & $2.285^{* * *}$ & 1.203 & 0.592 \\
\hline
\end{tabular}




\begin{tabular}{|c|c|c|c|c|c|c|c|c|c|}
\hline & [8.02] & {$[-1.62]$} & {$[-5.53]$} & [6.40] & {$[-0.77]$} & {$[-2.45]$} & [5.69] & [1.39] & {$[-1.40]$} \\
\hline \multirow[t]{2}{*}{ Scotland } & $1.628^{* * *}$ & $0.732^{* * *}$ & $0.379 * * *$ & $1.679 * * *$ & 0.999 & $0.510^{* *}$ & $1.831 * * *$ & 1.026 & 0.634 \\
\hline & [13.3] & {$[-3.05]$} & {$[-7.63]$} & [6.23] & {$[-0.010]$} & {$[-2.14]$} & [4.70] & {$[0.23]$} & {$[-1.53]$} \\
\hline \multirow{2}{*}{$\begin{array}{l}\text { Northern } \\
\text { Ireland }\end{array}$} & $1.673^{* * *}$ & $0.754^{*}$ & $0.324^{* * *}$ & $1.634^{* * *}$ & $0.427^{* * *}$ & $0.287^{* *}$ & 0.952 & $0.461^{* * *}$ & $0.177^{* *}$ \\
\hline & [9.88] & [-1.79] & {$[-5.92]$} & [3.77] & {$[-3.22]$} & {$[-2.09]$} & {$[-0.21]$} & {$[-3.27]$} & {$[-2.38]$} \\
\hline \multirow[t]{2}{*}{ Constant } & $0.147^{* * *}$ & $0.029 * * *$ & $0.019 * * *$ & $0.196 * * *$ & $0.099 * * *$ & $0.019 * * *$ & $0.050 * * *$ & $0.064 * * *$ & $0.012^{* * *}$ \\
\hline & {$[-54.7]$} & {$[-39.7]$} & {$[-41.3]$} & {$[-23.8]$} & {$[-23.6]$} & {$[-19.6]$} & {$[-25.3]$} & {$[-26.5]$} & {$[-21.8]$} \\
\hline No of Obs. & 116,866 & 116,866 & 116,866 & 22,288 & 22,288 & 22,288 & 18,620 & 18,620 & 18,620 \\
\hline $\begin{array}{l}\text { Pseudo r- } \\
\text { squared }\end{array}$ & 0.03 & & & 0.04 & & & 0.09 & & \\
\hline
\end{tabular}


Table 6: Mincerian earning equations (Dependent Variable: LnSalary)

\begin{tabular}{|c|c|c|c|c|c|}
\hline & All & Non-bohemians & Creative arts \& design & Creative media & $\begin{array}{l}\text { Other } \\
\text { creative }\end{array}$ \\
\hline \multicolumn{6}{|l|}{ Personal Characteristics } \\
\hline \multirow[t]{2}{*}{ Female } & $-0.044^{* * *}$ & $-0.046 * * *$ & $-0.054 * * *$ & 0.012 & $-0.082 * * *$ \\
\hline & {$[-16.1]$} & {$[-16.0]$} & {$[-4.33]$} & {$[0.92]$} & {$[-4.23]$} \\
\hline \multicolumn{6}{|c|}{ Age on graduation (ref: 21 and under) } \\
\hline \multirow[t]{2}{*}{$22-24$} & $0.062 * * *$ & $0.064 * * *$ & 0.016 & $0.024 *$ & $0.122 * * *$ \\
\hline & {$[18.5]$} & [17.9] & {$[1.15]$} & [1.89] & {$[4.93]$} \\
\hline \multirow[t]{2}{*}{$25+$} & $0.223^{* * *}$ & $0.231 * * *$ & $0.102 * * *$ & $0.148 * * *$ & $0.202 * * *$ \\
\hline & {$[49.6]$} & [48.9] & {$[4.34]$} & {$[6.48]$} & {$[6.30]$} \\
\hline \multirow[t]{2}{*}{ Disabled } & $-0.026^{* * *}$ & $-0.032 * * *$ & 0.005 & 0.016 & -0.009 \\
\hline & {$[-4.90]$} & {$[-5.85]$} & {$[0.27]$} & {$[0.58]$} & {$[-0.31]$} \\
\hline \multicolumn{6}{|l|}{ Ethnicity (ref: white) } \\
\hline \multirow[t]{2}{*}{ Black } & $-0.016^{*}$ & $-0.026 * * *$ & $0.105^{* *}$ & 0.024 & 0.019 \\
\hline & {$[-1.88]$} & {$[-2.96]$} & {$[2.31]$} & {$[0.85]$} & {$[0.24]$} \\
\hline \multirow[t]{2}{*}{ Asian } & -0.009 & $-0.012^{* *}$ & 0.016 & $0.065^{*}$ & 0.008 \\
\hline & {$[-1.60]$} & {$[-2.18]$} & {$[0.41]$} & [1.94] & {$[0.30]$} \\
\hline \multirow[t]{2}{*}{ Mixed } & $-0.020^{*}$ & -0.021 & -0.028 & 0.03 & -0.078 \\
\hline & {$[-1.67]$} & {$[-1.59]$} & {$[-0.61]$} & [0.69] & {$[-1.38]$} \\
\hline \multirow[t]{2}{*}{ Other } & -0.002 & 0.01 & -0.152 & $-0.151^{*}$ & 0.098 \\
\hline & {$[-0.13]$} & {$[0.58]$} & {$[-1.49]$} & {$[-1.82]$} & {$[0.62]$} \\
\hline \multicolumn{6}{|c|}{ Degree Classification (ref: Upper second) } \\
\hline \multirow[t]{2}{*}{ First } & $0.018^{* * *}$ & $0.019 * * *$ & -0.023 & $0.044 *$ & $0.058 * *$ \\
\hline & {$[4.20]$} & {$[4.42]$} & {$[-1.13]$} & {$[1.78]$} & {$[2.32]$} \\
\hline \multirow[t]{2}{*}{ Lower second } & $-0.015 * * *$ & $-0.012 * * *$ & $-0.029 * *$ & -0.018 & $-0.049 * *$ \\
\hline & {$[-5.10]$} & {$[-4.05]$} & {$[-2.22]$} & {$[-1.28]$} & {$[-2.43]$} \\
\hline \multirow[t]{2}{*}{ Third/pass } & 0.01 & $0.014^{* *}$ & -0.016 & -0.05 & -0.056 \\
\hline & [1.59] & {$[2.12]$} & {$[-0.74]$} & {$[-1.37]$} & {$[-1.63]$} \\
\hline \multirow[t]{2}{*}{ Other degree class } & $0.183^{* * *}$ & $0.193^{* * *}$ & 0.059 & -0.063 & 0.02 \\
\hline & [31.9] & {$[33.1]$} & [1.09] & {$[-1.40]$} & {$[0.42]$} \\
\hline \multicolumn{6}{|c|}{ Institution Type (ref: New University) } \\
\hline \multirow[t]{2}{*}{ Russell group } & $0.037^{* * *}$ & $0.041 * * *$ & -0.04 & 0.019 & -0.016 \\
\hline & [10.9] & [11.8] & {$[-1.45]$} & {$[0.60]$} & {$[-0.67]$} \\
\hline Other old & -0.005 & $-0.006 *$ & 0.015 & 0.019 & $0.055^{*}$ \\
\hline
\end{tabular}




\begin{tabular}{|c|c|c|c|c|c|}
\hline & {$[-1.44]$} & {$[-1.67]$} & [0.87] & [1.05] & [1.87] \\
\hline \multirow[t]{2}{*}{ HE/FE Colleges } & $-0.023 * * *$ & $-0.017 * * *$ & $-0.051 * * *$ & -0.024 & 0.01 \\
\hline & {$[-4.88]$} & {$[-3.42]$} & {$[-3.33]$} & {$[-1.44]$} & {$[0.23]$} \\
\hline \multicolumn{6}{|c|}{ Bohemian Graduate Type (ref: Non-bohemian) } \\
\hline \multirow[t]{2}{*}{ Creative arts \& design } & $-0.109 * * *$ & & & & \\
\hline & {$[-18.0]$} & & & & \\
\hline \multirow[t]{2}{*}{ Creative media } & $-0.058 * * *$ & & & & \\
\hline & {$[-9.09]$} & & & & \\
\hline \multirow[t]{2}{*}{ Other creative } & $-0.084 * * *$ & & & & \\
\hline & {$[-8.97]$} & & & & \\
\hline \multicolumn{6}{|l|}{ Job Attributes } \\
\hline \multirow[t]{2}{*}{ Creative job } & $-0.011 * *$ & -0.006 & 0.01 & -0.005 & -0.01 \\
\hline & {$[-2.55]$} & {$[-1.21]$} & {$[0.53]$} & {$[-0.29]$} & {$[-0.37]$} \\
\hline \multirow[t]{2}{*}{ Part time } & $-0.329 * * *$ & $-0.314 * * *$ & $-0.410 * * *$ & $-0.346 * * *$ & $-0.376 * * *$ \\
\hline & {$[-45.9]$} & {$[-40.8]$} & {$[-17.3]$} & {$[-10.2]$} & {$[-6.41]$} \\
\hline \multirow[t]{2}{*}{ Freelance/self employed } & -0.032 & 0.018 & $-0.137 * * *$ & -0.094 & 0.101 \\
\hline & {$[-1.49]$} & [0.64] & {$[-3.32]$} & {$[-1.38]$} & {$[1.02]$} \\
\hline \multicolumn{6}{|l|}{ Region of Job (ref: South East) } \\
\hline \multirow[t]{2}{*}{ North East } & $-0.081 * * *$ & $-0.080 * * *$ & $-0.092 * * *$ & $-0.082 * * *$ & -0.057 \\
\hline & {$[-12.4]$} & {$[-11.6]$} & {$[-3.38]$} & {$[-2.91]$} & {$[-1.52]$} \\
\hline \multirow[t]{2}{*}{ North West } & $-0.061 * * *$ & $-0.060 * * *$ & $-0.055 * *$ & $-0.075 * * *$ & $-0.103 * * *$ \\
\hline & {$[-12.1]$} & {$[-11.2]$} & {$[-2.39]$} & {$[-3.31]$} & {$[-3.32]$} \\
\hline \multirow[t]{2}{*}{ Yorkshire \& Humberside } & $-0.076 * * *$ & $-0.072 * * *$ & $-0.123 * * *$ & $-0.084 * *$ & $-0.118 * * *$ \\
\hline & {$[-14.4]$} & {$[-13.0]$} & {$[-4.65]$} & {$[-2.54]$} & {$[-3.59]$} \\
\hline \multirow[t]{2}{*}{ East Midlands } & $-0.062 * * *$ & $-0.060 * * *$ & $-0.084 * * *$ & $-0.045^{*}$ & -0.032 \\
\hline & {$[-11.2]$} & {$[-10.4]$} & {$[-3.17]$} & {$[-1.65]$} & {$[-0.82]$} \\
\hline \multirow[t]{2}{*}{ West Midlands } & $-0.066 * * *$ & $-0.066 * * *$ & $-0.086 * * *$ & -0.026 & $-0.066^{*}$ \\
\hline & {$[-12.2]$} & {$[-11.6]$} & {$[-3.42]$} & {$[-1.02]$} & {$[-1.77]$} \\
\hline \multirow[t]{2}{*}{ East } & $-0.015 * * *$ & $-0.016 * * *$ & -0.015 & -0.001 & -0.008 \\
\hline & {$[-2.69]$} & {$[-2.63]$} & {$[-0.62]$} & {$[-0.046]$} & {$[-0.19]$} \\
\hline \multirow[t]{2}{*}{ Greater London } & $0.143 * * *$ & $0.147 * * *$ & $0.107 * * *$ & $0.141 * * *$ & $0.133^{* * *}$ \\
\hline & [31.4] & [30.1] & [5.84] & {$[6.75]$} & {$[4.36]$} \\
\hline \multirow[t]{2}{*}{ South West } & $-0.069 * * *$ & $-0.065 * * *$ & $-0.101 * * *$ & $-0.045^{*}$ & $-0.130 * * *$ \\
\hline & {$[-12.5]$} & {$[-11.2]$} & {$[-4.13]$} & {$[-1.69]$} & {$[-3.31]$} \\
\hline \multirow[t]{2}{*}{ Wales } & $-0.059 * * *$ & $-0.059 * * *$ & $-0.054^{*}$ & $-0.050^{*}$ & -0.057 \\
\hline & {$[-8.81]$} & {$[-8.36]$} & {$[-1.92]$} & {$[-1.70]$} & {$[-1.12]$} \\
\hline Scotland & $-0.119 * * *$ & $-0.121 * * *$ & -0.032 & -0.018 & $-0.201 * * *$ \\
\hline
\end{tabular}




\begin{tabular}{|c|c|c|c|c|c|}
\hline & {$[-19.6]$} & {$[-19.3]$} & {$[-0.91]$} & {$[-0.46]$} & {$[-3.79]$} \\
\hline \multirow[t]{2}{*}{ Northern Ireland } & $-0.140 * * *$ & $-0.137 * * *$ & $-0.139 * *$ & $-0.091 *$ & $-0.273 * * *$ \\
\hline & {$[-15.4]$} & {$[-14.5]$} & {$[-2.24]$} & {$[-1.90]$} & {$[-5.37]$} \\
\hline \multirow[t]{2}{*}{ Constant } & $9.421 * * *$ & $9.401 * * *$ & $9.538 * * *$ & $9.375^{* * *}$ & $9.325^{* * *}$ \\
\hline & [1222] & [1140] & [322] & [293] & [127] \\
\hline No of obs. & 61,197 & 53,455 & 4,275 & 2,322 & 1,145 \\
\hline R-squared & 0.43 & 0.43 & 0.31 & 0.36 & 0.44 \\
\hline \multicolumn{6}{|c|}{ Robust $t$ statistics in brackets ${ }^{* * *} p<0.01,{ }^{* *} p<0.05, * p<0.1$} \\
\hline \multicolumn{6}{|c|}{ Also includes controls for industry (SIC) and occupational group (SOC) } \\
\hline
\end{tabular}

between the three creative groups (chi-squared 219.45, p<0.00) 


\section{References}

ABREU M., FAGGIAN A., COMUNIAN R. and MCCANN P. (2011) "Life is short, art is long": the persistent wage gap between Bohemian and non-Bohemian graduates, The Annals of Regional Science, 1-17, Online First DOI: 0.1007/s00168-010-0422-4.

ASTON J. (1999) Ambitions and Destinations: the Careers and Retrospective Views of Art and Design Graduates and Postgraduates, International Journal of Arts and Design Education 18, 23140.

BAINES S. and WHEELOCK J. (2003) Creative livelihoods: The economic survival of visual artists in the North of England, Northern Economic Review 33/34, 118-33.

BALL L. (2003) Future Directions for Employability Research in the Creative Industries, pp. http://www.adm.heacademy.ac.uk/resources/resources-by-topic/employability/future-directions-foremployability-research-in-the-creative-industries (accessed 12th May 2009). Art, Design and Communication - Learning and Teaching Support Network / The Council for Higher Education in Art and Design (CHEAD) Brighton.

BANKS M. (2006) Moral Economy and Cultural Work, Sociology 40, 455-72.

BECKER G. S. (1964) Human Capital: A Theoretical and Empirical Analysis, with Special Reference to Education University of Chicago Press, Chicago.

BLAIR H. (2001) 'You're Only as Good as Your Last Job': the Labour Process and Labour Market in the British Film Industry, Work, Employment and Society 15, 149-69.

BLAIR H., GREY S. and RANDLE K. (2001) Working in film: employment in a project based industry, Personnel Review 30, 170-85.

BOSCHMA R. A. and FRITSCH M. (2009) Creative Class and Regional Growth: Empirical Evidence from Seven European Countries, Economic Geography 85, 391-423.

BOURDIEU P. (1993) The Field of Cultural Production. Essays on Art and Literature. Polity Press, Cambridge.

BOURDIEU P. (1996) The Rules of the Art. Genesis and Structure of the Literary Field. Polity Press, Cambridge.

CHAPAIN C. A. and COMUNIAN R. (2009) Creative Cities in England: Researching Realities and Images, Built Environment 35, 212-29.

CLIFTON N. (2008) The "creative class" in the UK: an initial analysis, Geografiska Annaler: Series B, Human Geography 90, 63-82.

COMUNIAN R. (2009) Questioning creative work as driver of economic development: the case of Newcastle-Gateshead, Creative Industries Journal 2.

COMUNIAN R. (2011) Rethinking the creative city: the role of complexity, networks and interactions in the urban creative economy, Urban Studies 48, 1157-79.

COMUNIAN R. and FAGGIAN A. (2011) Higher Education and the Creative City, in MELLANDER C., ANDERSSON A. and ANDERSSON D. (Eds) Handbook on Cities and Creativity Edward Elgar, London/ New York.

COMUNIAN R., FAGGIAN A. and JEWELL S. (2011) Winning and losing in the creative industries. An analysis of creative graduates' career opportunities across creative disciplines Cultural Trends 20, 291-308.

COMUNIAN R., FAGGIAN A. and LI Q. C. (2010) Unrewarded careers in the creative class: The strange case of Bohemian graduates, Papers in Regional Science 89389 - 410

COMUNIAN R., SMITH D. and TAYLOR C. (forthcoming) The role of universities in the regional creative economies of the UK: hidden protagonists and the challenge of knowledge transfer,

European Planning Studies.

CREWE L. (1996) Material Culture: Embedded Firms, Organizational Networks and the Local Economic Development of a Fashion Quarter, Regional Studies: The Journal of the Regional Studies Association, pp. 257-72. 
CUNNINGHAM S., CUTLER T., HEARN G., RYAN M. and KEANE M. (2004) An innovation agenda for the Creative Industries: Where is the R\&D?, Media International Australia:

incorporating Culture \& Policy 112, 174-85.

CURRID E. (2007) The Warhol Economy: How Fashion, Art and Music Drive New York City.

Princeton University Press, Princeton.

DCMS (1998) Creative Industries Mapping Document Department for Culture, Media and Sport, London.

DCMS (1999a) Creative Industries - The regional dimension. Department for Culture, Media and Sport, London.

DCMS (1999b) Creative Industries Exports - Our hidden potential. Department for Culture, Media and Sport, London.

DCMS (2001) Creative Industries Mapping Document Department for Culture, Media and Sport, London.

DCMS (2003) Regional Cultural Data Framework, a report by Positive Solutions, Business

Strategies, Burns Owens Partnership and Andy C. Pratt. DCMS (Department for Media, Culture and Sport), London.

DCMS (2010) Creative Industries Economic Estimates. DCMS, London.

DCMS and BIS (2009) Digital Britain: Final Report. Department for Culture, Media, Sport and Department for Business, Innovation and Skills., London.

EIKHOF D. R. and HAUNSCHILD A. (2006) Lifestyle Meets Market: Bohemian Entrepreneurs in Creative Industries, Creativity and Innovation Management 15, 234 - 41.

EKINSMYTH C. (2002) Project Organization, Embeddedness and Risk in Magazine Publishing, Regional Studies: The Journal of the Regional Studies Association, 229-43.

FAGGIAN A. and MCCANN P.(2006) "Human Capital and Regional Knowledge Assets: a

Simultaneous Equation Model”, Oxford Economic Papers, 58 (3), 475-500

FAGGIAN A. and MCCANN P. (2009a), "Human capital, graduate migration and innovation in British Regions", Cambridge Journal of Economics, 33, 317-333

FAGGIAN A. and MCCANN P. (2009b) "Human Capital and Regional Development" in Capello R. and Nijkamp P. (eds.), Handbook of Regional Growth and Development Theories, Edward Elgar, Cheltenham, 131-151

FAGGIAN A., MCCANN P. and SHEPPARD S. (2007a) "Human Capital, Higher Education and Graduate Migration: An Analysis of Scottish and Welsh Students", Urban Studies, 44 (13), 25112528

FAGGIAN A., MCCANN P. and SHEPPARD S. (2007b) "Some evidence that women are more mobile than men: Gender differences in UK graduate migration behavior", Journal of Regional Science, 47 (3), 517-539

FLORIDA R. (2002) The Rise of the Creative Class. Basic Books, New York.

FLORIDA R. (2003) Cities and Creative Class, City and Community 2, 3-19.

FLORIDA R. (2006) The Flight of the Creative Class. HarperBusiness, New York.

FLORIDA R., MELLANDER C. and STOLARICK K. (2008) Inside the black box of regional development--human capital, the creative class and tolerance, Journal of Economic Geography $\mathbf{8}$, 615-49.

FREAKLEY V. and NEELANDS J. (2003) The UK Artist's World of Work, Research in Dance Education 4, 51-61.

GALLOWAY S. and DUNLOP S. (2006) Deconstructing the Concept of 'Creative Industries', in EISENBERG C., GERLACH R. and HANDKE C. (Eds) Cultural Industries: The British Experience in International Perspective. Humboldt University Berlin, Online. 
GARNHAM N. (2005) From cultural to creative industries. An analysis of the implications of the "creative industries" approach to arts and media policy making in the United Kingdom, International Journal of Cultural Policy 11, 15-29.

GILL R. (2002) Cool, Creative and Egalitarian? Exploring Gender in Project-Based New Media Work in Europe, Information, communication and society 5, 70-89.

GLA (2002) Creativity: London's Core Business. Greater London Authority, London.

GLA (2004) London's Creative Sector: 2004 Update. Greater London Authority, London.

GLA (2007) Working Paper 22: London's Creative Sector: 2007 Update. Greater London Authority, London.

GLAESER E. L. (2005) Review of Richard Florida's "The Rise of the Creative Class", Regional Science and Urban Economics 35, 593-6.

GRABHER G. (2004) Learning in projects, remembering in networks? Communality, sociality and connectivity in project ecologies, European Urban and Regional Studies 11, 99 -119.

HESMONDHALGH D. and BAKER S. (2008) Creative Work and Emotional Labour in the Television Industry, Theory, Culture and Society 25, 97-118.

HRACS B. J. (2009) Beyond Bohemia: Geographies of everyday creativity for musicians in Toronto, in EDENSOR T., LESLIE D., MILLINGTON S. and RANTISI N. M. (Eds) Spaces of Vernacular Creativity: Rethinking the Cultural Economy. Routledge, London.

JAYNE M. (2005) Creative industries: the regional dimension?, Environment \& Planning C: Government \& Policy 23, 537 - 56.

JONES C. (1996) Careers in project networks: The case of film industry, in ARTHUR M. B. and ROUSSEAU D. M. (Eds) The boundaryless career: a new employment principle for a new organisational era. Oxford University Press, New York.

JUUTI S. and LITTLETON K. (forthcoming) Musical identities in transition: Solo-piano students' accounts of entering the academy, Psychology of Music.

KLOOSTERMAN R. C. (2010) Building a career: labour practices and cluster reproduction in Dutch Architectural Design, Regional Studies 44, 859-71.

KNELL J. and OAKLEY K. (2007) London's Creative Economy: An Accidental Success? The Work Foundation, London.

LONDON HIGHER (2005) The Creative Capital: Exploring London's creative education sector London Higher, London.

LORENZEN M. and FREDERIKSEN L. (2005) The management of projects and product experimentation: examples from the music industry

European Management Review 2, 198-211.

MARKUSEN A. (2006) Urban Development and the Politics of a Creative Class: Evidence from the case Study of Artists, Environment and Planning A 38, 1921 - 40

MARKUSEN A. and SCHROCK G. (2006) The Artistic Dividend: Urban Artistic Specialisation and Economic Development Implications, Urban Stud 43, 1661-86.

MCAULEY A. and FILLIS I. (2005) Careers and Lifestyles of Craft Makers in the 21st Century, Cultural Trends 14, 139 - 56.

MCROBBIE A. (2002) Clubs to Companies: Notes on the Decline of Political Culture in speeded up Creative worlds, Cultural Studies 16, 516-31.

MELLANDER C. (2009) Creative and Knowledge Industries: An Occupational and Distribution Approach, Economic Development Quarterly 23, 294 - 305.

MELLANDER C. and FLORIDA R. (2007) The Creative Class or Human Capital? - explaining regional development in Sweden, KTH / CESIS, Electronic Working Paper Series in Economics and Institutions of Innovation Paper No. 79.

NEFF G. (2004) The Changing Place of Cultural Production: The Location of Social Networks in a Digital Media Industry, Annals, AAPSS. 
NESTA (2003) Forward thinking - New Solutions to Old Problems: Investing in the Creative Industries. NESTA, London.

NESTA (2008a) The art of innovation: how fine arts graduates contribute to innovation. NESTA, London.

NESTA (2008b) Beyond the creative industries: mapping the creative economy in the United Kingdom. NESTA London.

NESTA (2009) The geography of creativity. NESTA, London.

NIXON S. and CREWE B. (2004) Pleasure at work? Gender,consumption and work-based identities in the creative industries, Consumptiion Markets \& Culture 7, 129 - 47.

OAKLEY K. (2009) From Bohemian to Britart - art students over 50 years, Cultural Trends 18, 281 $-94$.

OLFERT M. R. and PARTRIDGE M. D. (2011) Creating the Cultural Community: Ethnic Diversity vs. Agglomeration, Spatial Economic Analysis 6, 25-55.

PRATT A. C. (1997) The cultural industries production system: a case study of employment change in Britain, 1984-91, Environment and Planning A 29, 1953-74.

REIMER S., PINCH S. and SUNLEY P. (2008) Design Spaces: Agglomeration and Creativity in British design agencies, Geografiska Annaler: Series B, Human Geography 90, 151-72.

ROSS A. (2003) No Collar: The Humane Workplace and Its Hidden Costs. Basic Books, New York. SHATTOCK M. (2010) Managing Mass Higher Education in a Period of Austerity, Arts and Humanities in Higher Education 9, 22-30.

SPENCE M. (1973) Job Market Signaling, Quarterly Journal of Economics 87, 355-74

STOLARICK K. and FLORIDA R. (2006) Creativity, connections and innovation: a study of linkages in the Montréal Region, Environment and Planning A 38, 1799 - 817

SUNLEY P., PINCH S. and MACMILLEN J. (2010) Growing Design? Challenges and Constraints Facing Design Consultancies in Three English City-Regions, Regional Studies 44, 873 - 87.

TAYLOR C. (2006) Beyond Advocacy: Developing an Evidence Base for Regional Creative Industry Strategies, Cultural Trends 15, 3 -18.

TAYLOR S. and LITTLETON K. (2008) Art work or money: Conflicts in the construction of a creative identity, Sociological Review 56, 275-92.

VINODRAI T. (2006) Reproducing Toronto's Design Ecology: Career Paths, Intermediaries, and Local Labor Markets, Economic Geography 82, 237-63. 
'In Florida's own words, at the core of the creative class there are 'people in science and engineering, architecture and design, education, arts, music and entertainment, whose economic function is to create new ideas, new technology, and/or new creative content', but also 'the creative professionals in business and finance, law, healthcare and related fields. These people engage in complex problem solving that involves a great deal of independent judgment and requires high levels of education or human capital' (Florida 2002, p. 8)

ii For more information on the Joint Academic Coding System (JACS) see http://www.hesa.ac.uk/index.php?option=com_content\&task=view\&id=158\&ltemid=233

iii In detail, these include: Fine Arts: W110 Drawing, W120 Painting, W130 Sculpture, W140 Printmaking, W150 Calligraphy, W160 Fine Art Conservation, W190 Fine Art not elsewhere classified; Design: W210 Graphic Design, W211 Typography, W212 Multimedia Design, W213 Visual Communication, W220 Illustration, W230 Clothing/Fashion Design, W231 Textile Design, W240 Industrial/Product Design, W250 Interior Design, W260 Furniture Design, W270 Ceramics Design, W280 Interactive and Electronic Design, W290 Design studies not elsewhere classified; Music: W310 Musicianship/Performance studies, W330 History of Music, W340 Types of Music, W350 Musicology, W360 Musical Instrument History, W390 Music not elsewhere classified; Drama: W410 Acting, W420 Directing for Theatre, W430 Producing for Theatre, W440 Theatre studies, W450 Stage Management, W451 Theatrical Wardrobe Design, W452 Theatrical Make-up, W460 Theatre Design, W461 Stage Design, W490 Drama not elsewhere classified; Dance: W510 Choreography, W520 Body Awareness, W530 History of Dance, W540 Types of Dance, W590 Dance not elsewhere classified; Cinematics and Photography: W610 Moving Image Techniques, W611 Directing Motion Pictures, W612 Producing Motion Pictures, W613 Film \& Sound Recording, W614 Visual and Audio Effects, W615 Animation Techniques, W620 Cinematography, W630 History of Cinematics and Photography, W631 History of Cinematics, W632 History of Photography, W640 Photography, W690 Cinematics and Photography not elsewhere classified; Crafts: W710 Fabric and Leather Crafts, W711 Needlecraft, W712 Dressmaking, W713 Soft Furnishing, W714 Weaving, W715 Leatherwork, W720 Metal Crafts, W721 Silversmithing/Goldsmithing, W722 Blacksmithing, W723 Clock/Watchmaking, W730 Wood Crafts, W731 Carpentry/Joinery, W732 Cabinet making, W733 Marquetry and Inlaying, W734 Veneering, W740 Surface Decoration, W750 Clay and Stone Crafts, W751 Pottery, W752 Tile Making, W753 Stone Crafts, W760 Reed Crafts, W761 Basketry, W762 Thatching, W770 Glass Crafts, W771 Glassblowing, W780 Paper Crafts, W781 Bookbinding, W782 Origami, W790 Crafts not elsewhere classified; Imaginative Writing: W810 Scriptwriting, W820 Poetry Writing, W830 Prose Writing, W890 Imaginative Writing not elsewhere classified; Others in Creative Arts and Design: W990 Creative Arts and Design not elsewhere classified.

iv These include: Information Services: P110 Information Management, P120 Librarianship, P121 Library Studies, P130 Curatorial Studies, P131 Museum Studies, P132 Archive Studies, P190 Information Services not elsewhere classified; Publicity Studies: P210 Public Relations, P290 Publicity studies not elsewhere classified; Media studies: P301 Television studies, P302 Radio studies, P303 Film studies, P304 Electronic Media studies, P305 Paper-based Media studies, P310 Media Production, P311 Television Production, P312 Radio Production, P313 Film Production, P390 Media studies not elsewhere classified; Publishing: P410 Electronic Publishing, P411 Publishing on audio/video tape, P412 Publishing on CD-ROM, P413 Publishing via the World Wide Web, P420 Multi-media Publishing, P430 Interactive Publishing, P490 Publishing not elsewhere classified; Journalism: P510 Factual Reporting, P590 Journalism not elsewhere classified; Others in Mass 
Communications and Documentation: P990 Communications and Documentation not elsewhere classified.

${ }^{v}$ In the UK the degree classification system has the following classifications: first, upper second, lower second, third and pass.

vi Rt Hon Jeremy Hunt MP, "Arts keynote speech", 19 May 2010, The Roundhouse, London. Script available at http://www.culture.gov.uk/news/ministers_speeches/7069.aspx 